\title{
RESULTS OF MAINZ-POUCH II TRANSRECTAL URINARY DIVERSION FROM A SINGLE CENTER
}

\author{
O.E. Stakhovsky, A.V. Tymoshenko, O.A. Voilenko, Yu.V. Vitruk, \\ O.A. Kononenko, M.V. Pikul, E.O. Stakhovsky
}

\section{National Cancer Institute of the Ministry of Health of Ukraine}

Introduction. Surgical complexity in invasive bladder cancer is not only in the extirpative aggressive cystectomy, but also in the effectiveness of urinary diversion. The latter is important for the quality of patients' life greatly affecting their working ability. Many methods of post-cystectomy urinary diversions have been currently developed, indicating no single approach solving the problem. Post-cystectomy controlled urination is believed to be one of the key aspects of the quality of a patient's life.

The sigmoid colon and anal sphincter were first used after cystectomy for controlled urination in 1852 [1]. Ureterosigmoidostomy, as a method of controlled urination, was actively used during the first half of the 19th century. But such complications as electrolyte imbalance, urinary incontinence, frequent exacerbations of pyelonephritis, impaired renal function and others were considered as an obstacle for its widespread use. Many different modifications have been developed, over 60 ways of transrectal urinary diversion, but none of them seemed to be satisfactory [2]. Unsuccessful results of ureterosigmoidostomy and an alternative method of urinary diversion suggested by Bricker in the early 1950s resulted in decrease in the use of ureterosigmoidostomy as a post-cystectomy urinary diversion method [3]. In 1991, in order to overcome typical disadvantages of classical ureterosigmoidostomy, it was modified to provide for a low pressure reservoir by the rectosigmoid detubularization. Longitudinal dissection of the sigmoid colon disrupts the circular muscles integrity and contractile activity, decreasing pressure in the reservoir and thus improving urine retention and its excretion from the kidneys. This method of urinary diversion is characterized by pathophysiological and clinical advantages and called "Mainz Pouch II" [4, 5, 6].

Most patients with invasive bladder cancer consider a urinary stoma on the anterior abdominal wall unacceptable; this case also requires for the first disability group adversely affecting working ability. On the other hand, controlled urinary diversion was found to improve the quality of postcystectomy patients' life and to be most acceptable to most urologists and patients [7]. Based on the above, the purpose of the study was to evaluate results of MP II surgery, as a method of postcystectomy controlled urinary diversion.

Clinical material. Clinical, retrospective analysis was conducted for 118 patients with invasive bladder cancer that were treated with radical cystectomy followed by Mainz II transrectal urinary diversion. Before surgery, the patients were evaluated under a standardized diagnostic protocol, including: physical examination, lab blood and urine tests, PSA blood test, gastroscopy, urinary tract radiography, excretory urography, cystouretheroscopy, nephroscintigraphy, CT, urinary cytology. Anal sphincter competence was evaluated with insertion of $300-400 \mathrm{ml}$ of saline solution into the rectum, holding the solution for above 3 hours was considered satisfactory.

Indications for Mainz-II surgery included: invasive bladder cancer with the prostate or urethra lesions, refusal of the patient from external urinary diversion, bladder extrophy, small intestine mesentery, preserved kidney function, plasma creatinine $<10 \mathrm{~mm}$ 1. Comparative characteristics of the patient baseline are shown in Table 1.

Contraindications included: anal sphincter dysfunction, sigmoid diverticulosis, bilateral ureterohydronephrosis, decreased renal function (serum creatinine level $>1.5 \mathrm{mg} / \mathrm{ml}$ ), solitary kidney, colon polyposis, rectal fissures, rectum damage during cystectomy.

It should be noted that prior to admission to the $c \backslash$ hospital, 38 (32\%) patients went through organ-preserving surgical interventions even having a proof of muscle invasion. $92(78 \%)$ patients had advanced disease stages. Unilateral ureterhydronephrosis (UHN) of varying severity occurred in $43(36 \%)$ cases.

Surgery: Mainz-pouch II surgery was conducted according to the procedure described by M. Fish and co-authors [8, 4, 9, 10]. Upon radical cystectomy, the sigmoid colon was dissected for 12- 
Comparative evaluation of baseline data in the study groups, $n=118$

\begin{tabular}{|l|l|c|c|}
\hline \multicolumn{2}{|c|}{ Indicators } & Statisticalunits & Number of patients \\
\hline \multirow{2}{*}{ Gender } & male & $\mathrm{n}(\%)$ & $84(71)$ \\
\cline { 2 - 4 } & female & $\mathrm{n}(\%)$ & $34(29)$ \\
\hline \multirow{3}{*}{ Age } & $\geq 60$ & $\mathrm{n}(\%)$ & $81(69)$ \\
\cline { 2 - 4 } & $<60$ & $\mathrm{n}(\%)$ & $37(31)$ \\
\hline \multirow{4}{*}{$\mathrm{N}$} & 2 & $\mathrm{n}(\%)$ & $26(39.4)$ \\
\cline { 2 - 4 } & 3 & $\mathrm{n}(\%)$ & $57(45.1)$ \\
\cline { 2 - 4 } & 4 & $\mathrm{n}(\%)$ & $35(15.5)$ \\
\hline \multirow{3}{*}{$\mathrm{N}$} & 0 & $\mathrm{n}(\%)$ & $86(72.8)$ \\
\cline { 2 - 4 } & 1 & $\mathrm{n}(\%)$ & $32(27.2)$ \\
\hline \multirow{3}{*}{$\mathrm{M}$} & 0 & $\mathrm{n}(\%)$ & $118(100)$ \\
\cline { 2 - 4 } & 1 & $\mathrm{n}(\%)$ & 0 \\
\hline UHN & & $\mathrm{n}(\%)$ & $43(36.4)$ \\
\hline
\end{tabular}

$18 \mathrm{~cm}$, the detubularized segment of the intestine was arranged as $\mathrm{U}$-shaped, the posterior wall was restored with a two-row continuous, vicryl (3-0) suture, the ureter was implanted under the CameyLe Duc method [11]; distal ends of the ureter drainage were fixed to the mucosa and placed in the rectum; the latter was also drained with a rectal probe for 8-12 days. The front wall of the reservoir was restored with a two-row continuous suture. The surgery duration varied from 180 to 270 minutes, depending on case complexity.

All patients received prophylactic treatment with antibiotics, anticoagulants, etc. in the perioperative period.

Results. Intraoperative complications during the MP II occurred in six (5\%) patients (damage to external ileac veins -1 , arteries -1 , obturative nerves -1 , bladder bed bleeding -3 ) with recurrent muscle-invasive bladder cancer. Complications were due to distort anatomy after surgical and radiation treatments. Blood loss during surgery was 170$3000(788.51 \pm 141.3) \mathrm{ml}$. Complications in the early post MP II period (up to 30 days after surgery) occurred in $29(24.5 \%)$ patients and were associated with impaired function of organs and systems, infectious purulent inflammation, anastomosis failure (Table 2).

Postoperative septic complications were seen during implementation of the technique in patients
(8) after pelvic irradiation. 3 patients were taking back to the OR due reservoir failure and peritonitis development. Inadequate urine flow from kidney drainages, caused exacerbation of pyelonephritis and renal failure. That usually were observed upon the rectal probe removal and restored urine flow through the anal sphincter. The causes of cardiovascular complications were in $3(2.5 \%)$ patients and led to fatal events included: acute myocardial infarction (2) and cerebral circulatory disorders (1). Late complications were evaluated in a total of 94 patients for over 12 months (Table 3).

Metabolic acidosis, exacerbation of pyelonephritis and CKD were the most common complications in the MP II postoperative longterm period. Metabolic disorders caused by absorbed urine in the colon were observed in $37(39.3 \%)$ patients, $8(8.5 \%)$ of them required treatment in the hospital. In other cases, acidosis was managed under outpatient conditions with alkaline solutions and potassium preparations.

Deterioration of renal function and urodynamics in the upper urinary tract occurred in $31(33 \%)$ cases. These disorders were based on two mutually opposite complications: ureteroenteric anastomosis stenosis (13) and ureteroenteric gas reflux (18), resulted in pyelonephritis and impaired renal function. Pyelonephritis exacerbation due to reflux was sporadic and effectively eliminated with

Table 2

Complications of the early postoperative period, $n=118$

\begin{tabular}{|l|c|c|}
\hline \multicolumn{1}{|c|}{ Complication } & Quantity, $\mathrm{n}$ & Percentage ratio,\% \\
\hline Suppuration of the postoperative wound & 10 & 8.4 \\
\hline Reservoir suture failure & 3 & 2.5 \\
\hline Urinary tract infection & 11 & 9.3 \\
\hline Cardiovascular system disorders & 5 & 4.2 \\
\hline
\end{tabular}


Complications of the late postoperative period, $n=94$

\begin{tabular}{|l|c|c|}
\hline \multicolumn{1}{|c|}{ Complication } & Quantity, $\mathrm{n}$ & Percentage ratio, \% \\
\hline Metabolic acidosis & 37 & 39.3 \\
\hline Ureteral reflux & 18 & 19.1 \\
\hline Ureteroenteric stenosis anastomosis & 13 & 13.9 \\
\hline Night urination incontinence & 3 & 3.1 \\
\hline
\end{tabular}

anti-inflammatory and antibacterial drugs. In contrast, pyelonephritis caused by ureteroenteric anastomosis stenosis proceeded more aggressively and required for temporary unilateral (6) or bilateral (3) nephrostomy. Three patients with strictures of ureteroenteric intestinal anastomosis undergone reoperations for the ureter reanastomosis.

All patients hold urine during the day, but $3.1 \%$ of patients suffered from night urinary incontinence, which required bladder pads and sleep interruption with bedwetting alarm. Over time, patients coped to answer the call of nature, and this complication gradually resolved.

The average urination frequency during the day and night was $5.1 \pm 1.1$ and $2.0 \pm 0.5$, respectively.

Discussion. Radical cystectomy with reconstruction of the lower urinary tract remains the gold standard for treatment of patients with muscle invasive bladder cancer. In recent years, various methods of reconstruction of the lower urinary tract after cystectomy have been widely used. Conventionally, they can be divided into 2 groups: continental, involving controlled urinary diversion and incontinent - uncontrolled leakage of urine.

Deciding which procedures to recommend to the patient, all indications and contraindications, functional outcome, possible short and long-term complications, physical and psychosocial aspects should be taken into consideration. Urinary diversion methods controlling urination after cystectomy are believed to be the most acceptable and important for the quality of life of patients.

In this study, urine derivation was evaluated under the post-cystectomy MP II method that is ureterosigmoidostomy, a modified classic operation.

Ureterosigmoidostomy was severely criticized, mainly because of complications occurred in $80 \%$ of cases [18, 19]. Urodynamic studies in patients with classical ureterosigmoidostomy have shown that active contractions of the intestinal muscles lead to increased pressure in the rectum, often causing urinary incontinence and impaired urodynamics [12, 13]. A sigma rectum pouch was designed to overcome such disadvantages. Therefore, we have specifically focused on studying complications of this relatively new technique, i.e. a urinary pouch, controlled by an anal sphincter, considered as an attractive way of urine excretion for patients unable to urinate, decreasing the need for stomas or collection devices.

Unlike ureterosigmoidostomy, urinary diversion under the MP II method involves a low pressure reservoir. Postoperative rectodynamic studies have shown that a sigmoidorectal pouch is a low pressure reservoir even at large volume of filling, and the detubularized and reconfigured intestine walls have no coordinated contractions $[4,9,10,14$, 17].

A level of early postoperative complications made $24.5 \%$ and was similar to the results of other works $[8,15,16,17]$. The sigma rectum pouch is characterized by the following complications in the long postoperative period - electrolyte imbalance, impaired renal function due to anastomosis strictures or reflux and pyelonephritis. However, none of these complications is unique to this type of urinary diversion except for urinary incontinence. The latter was absent during the day and occurred at night in $3.1 \%$ of cases. The main disadvantage of the MP II procedure was metabolic acidosis, which can be managed with oral alkaline therapy, and we used it prophylactically in all patients.

\section{Conclusion}

The Mainz II rectosigmoid pouch is believed to be an effective method of controlled urinary diversion and may be an option for patients with bladder cancer advanced to prostate or urethra, and unwilling to have a stoma with a urine collector. Although the rectosigmoid pouch has the risk of metabolic acidosis in $39 \%$ and of ureterohydronephrosis in $8 \%$, this method of urinary diversion has low rates of mortality and complications. Such approach may be good for bladder control and an attractive alternative to other urinary diversion forms. 


\section{Список літератури}

1. Simon J. Ectopia vesicae (absence of the anterior walls of the bladder and pubis abdominal parietes); operation for directing the orifices of the uterus into the rectum; temporary success; subsequent death; autopsy. Lancet. 1892. No. 2. P. 568-570.

2.Hinman F.,Weyrauch H.M.Jr. A critical study of the different principles of surgery which have been used in uretero-intestinal implantation. Trans Am Assoc Genitourin Surg. 1936. No. 29. P. 15-16.

3. Stamey T.A. The pathogenesis and implications( of the electrolyte imbalance in ureterosigmoidostomy. Surg Gynecol Obstet. 1956. No. 103. P. 736-758.

4. Fisch M., Wammack R., Muller S.C., Hohenfellner R. The Mainz pouch II (sigma rectum pouch). J Urol. 1993. No. 149. P. 258-263.

5. Gerharz E.W., Kuhl U.N., Weingartner K. et al. Experience with the Mainz modification of ureterosigmoidostomy. Br J Surg. 1998. No. 85. P. 1512-1516.

6. Woodhouse C.R.J., Christofides M. Modified ureterosigmoidostomy (Mainz II) - technique and early results. Br J Urol. 1998. No. 81. P. 247-252.

7. Lee R.K., Abol-Enein H., Artibani W., Bochner B., Dalbagni G., Daneshmand S., Fradet Y., Hautmann R.E., Lee C.T., Lerner S.P. et al. Urinary diversion after radical cystectomy for bladder cancer: Options, patient selection, and outcomes. BJU Int. 2014. No. 113. P. 11-23.

8. Fisch M., Wammack R., Muller S.C., Hohenfellner R. The sigma rectum pouch (Mainz pouch II). World. J. Urol. 1996. No. 14. P. 68-72.

9. Fisch M., Wammack R., Muller S.C., Hohenfellner R. The Mainz pouch II. Eur. Urol. 1994. No. 25. P. 7-15.

10. Fisch M., Wammack R., Steinbach F., Muller S.C., Hohenfellner R. Sigma-rectum pouch (Mainz pouch II). Urol. Clin. North Am. 1993. No. 20. P. 561-569.

11. Le Duc A., Camey M., Teillac P. An original antireflux ureteroileal implantation technique: long term follow-up. J Urol. 1987. No. 137. P. 1156-1158.

12. Kock N.G., Ghoneim M.A., Lycke K.G., Mahran M.R. Urinary diversion to the augmented and valved rectum: Preliminary results with a novel surgical procedure. J Urol. 1988. No. 140. P. 1375-1379.

13. Ghoneim M.A., Shehab El-Din A.B., Ashamallah A.K., Gaballah M.A. Evolution of the rectal bladder as a method for urinary diversion. J Urol. 1981. No. 126. P. 737-740.

14. Gilja I., Kovacic M., Radej M., Kosuta D., Bakula B., Goles L. The sigmoidorectal pouch (Mainz pouch II). Eur. Urol. 1996. No. 29. P. 210-215.

15. Chang S.S., Cookson M.S., Baumgartner R.G., Wells N., Smith J.A. Analysis of early complications after radical cystectomy: results of a collaborative care pathway. J Urol. 2002. No. 167. P. 2012-2016.

16. Obek C., Kural A.R., Ataus S. et al. Complications of the Mainz Pouch II (sigma rectum pouch). Eur Urol. 2001. No. 39. P. 204-211.

17. Hadzi-Djokic J.B., Basic D.T. A modified sigma-rectum pouch (Mainz pouch II) technique: analysis of outcomes and complications on 220 patients. BJU. 2006. No. 97. P. 587-591.

18. Ferris O.D., Odel H.M. Electrolyte pattern of the blood after bilateral ureterosigmoidostomy. JAMA. 1950. No. 142. P. 634-641.

19. Stamey T.A. The pathogenesis and implications of the electrolyte imbalance in ureterosigmoidostomy. Surg Gynecol Obstet. 1956. No. 103. P. 736-758.

\section{References}

1. Simon, J. (1892). Ectopia vesicae (absence of the anterior walls of the bladder and pubis abdominal parietes); operation for directing the orifices of the uterus into the rectum; temporary success; subsequent death; autopsy. Lancet, 2, 568-570.

2.Hinman, F., \& Weyrauch, H.M.Jr. (1936).A critical study of the different principles of surgery which have been used in uretero-intestinal implantation. Trans Am Assoc Genitourin Surg, 29, 15-16.

3. Stamey, T.A. (1956). The pathogenesis and implications( of the electrolyte imbalance in ureterosigmoidostomy. Surg Gynecol Obstet, 103, 736-758.

4. Fisch, M., Wammack, R., Muller, S.C., \& Hohenfellner, R. (1993). The Mainz pouch II (sigma rectum pouch). J Urol, 149, 258-263. 
5. Gerharz, E.W., Kuhl, U.N., Weingartner, K., et al. (1998). Experience with the Mainz modification of ureterosigmoidostomy. Br J Surg, 85, 1512-1516.

6. Woodhouse, C.R.J., \& Christofides, M. (1998). Modified ureterosigmoidostomy (Mainz II) technique and early results. Br J Urol, 81, 247-252.

7. Lee, R.K., Abol-Enein, H., Artibani, W., Bochner, B., Dalbagni, G., Daneshmand, S., Fradet, Y., Hautmann, R.E., Lee, C.T., Lerner, S.P., et al. (2014). Urinary diversion after radical cystectomy for bladder cancer: Options, patient selection, and outcomes. BJU Int, 113, 11-23.

8. Fisch, M., Wammack, R., Muller, S.C., \& Hohenfellner, R. (1996). The sigma rectum pouch (Mainz pouch II). World. J. Urol., 14, 68-72.

9. Fisch, M., Wammack, R., Muller, S.C., \& Hohenfellner, R. (1994). The Mainz pouch II. Eur. Urol., $25,7-15$.

10. Fisch, M., Wammack, R., Steinbach, F., Muller, S.C., \& Hohenfellner, R. (1993). Sigma-rectum pouch (Mainz pouch II). Urol. Clin. North Am, 20, 561-569.

11. Le Duc, A., Camey, M., \& Teillac, P. (1987). An original antireflux ureteroileal implantation technique: long term follow-up. J Urol, 137, 1156-1158.

12. Kock, N.G., Ghoneim, M.A., Lycke, K.G., \& Mahran, M.R. (1988). Urinary diversion to the augmented and valved rectum: Preliminary results with a novel surgical procedure. J Urol, 140, 1375-1379.

13. Ghoneim, M.A., Shehab El-Din, A.B., Ashamallah, A.K., \& Gaballah, M.A. (1981). Evolution of the rectal bladder as a method for urinary diversion. J Urol, 126, 737-740.

14. Gilja, I., Kovacic, M., Radej, M., Kosuta, D., Bakula, B., \& Goles, L. (1996). The sigmoidorectal pouch (Mainz pouch II). Eur. Urol., 29, 210-215.

15. Chang, S.S., Cookson, M.S., Baumgartner, R.G., Wells, N., \& Smith, J.A. (2002). Analysis of early complications after radical cystectomy: results of a collaborative care pathway. J Urol, 167, 2012-2016.

16. Obek, C., Kural, A.R., Ataus, S., et al. (2001). Complications of the Mainz Pouch II (sigma rectum pouch). Eur Urol, 39, 204-211.

17. Hadzi-Djokic, J.B., \& Basic, D.T. (2006). A modified sigma-rectum pouch (Mainz pouch II) technique: analysis of outcomes and complications on 220 patients. BJU, 97, 587-591.

18. Ferris, O.D., \& Odel, H.M. (1950). Electrolyte pattern of the blood after bilateral ureterosigmoidostomy. JAMA, 142, 634-641.

19. Stamey, T.A. (1956). The pathogenesis and implications of the electrolyte imbalance in ureterosigmoidostomy. Surg Gynecol Obstet, 103, 736-758.

\section{Реферат}

\section{РЕЗУЛЬТАТИ ТРАНСРЕКТАЛЬНОГО ВЇДВЕДЕННЯ СЕЧІ ЗА МЕТОДИКОЮ MAINZ-POUCH II}

О.Е. Стаховський, А.В. Тимошенко,

О.А. Войленко, Ю.В. Вітрук,

О.А. Кононенко, М.В. Пікуль,

Е.О. Стаховський

Мета. Оцінка результатів операції Mainzpouch II (МП II), як методу контрольованого відведення сечі після цистектомії.

Матеріали і методи. Клінічному аналізу підлягли 118 пацієнтів на інвазивний рак сечового міхура. Пацієнтів перед операцією оцінювали за допомогою стандартизованого діагностичного протоколу, також проводилася оцінка тривалості утримання сечі анальним сфінктером, як одне із протипоказань до хірургічного втручання.

\section{Реферат}

РЕЗУЛЬТАТЫ ТРАНСРЕКТАЛЬНОЙ ДЕРИВАЦИИ МОЧИ ПО МЕТОДИКЕ MAINZ-POUCH II

О.Е. Стаховский, А.В. Тимошенко,

О.А. Войленко, Ю.В. Витрук,

О.А. Кононенко, М.В. Пикуль,

Е.О. Стаховский

Цель. Оценка результатов операции Mainzpouch II (MП II), как метода контролируемого отведения мочи после цистэктомии.

Материалы и методы. Клинический анализ 118 пациентов с инвазивным раком мочевого пузыря. Перед операцией пациентов оценивали с помощью стандартизированного диагностического протокола, также проводилась оценка длительности удержания мочи анальным сфинктером, как одно из противопоказаний к оперативному вмешательству. 
Результати. Їнтраопераційні ускладнення при виконанні МП ІІ виникли у 6 (5\%) хворих. Ускладнення в ранньому післяопераційному періоді відмічено у $29(24,5 \%)$ пацієнтів та пов'язані з порушенням функції органів і систем, інфекційно-гнійними запаленнями, неспроможністю сформованого анастомозу. У віддаленому післяопераційному періоді ускладнення виявлені у $71(75,5 \%)$ хворого, що призводили до явищ метаболічного ацидозу 37 (39,3\%) та загострень інфекцій верхніх сечових шляхів, в основі яких лежали: стеноз сечовідно-кишкового анастомозу $13(13,9 \%)$ та кишково-сечовідний газовий рефлюкс 18 (19,1\%). Неконтрольоване сечовиділення вночі відмічено у $3(3,1 \%)$ хворих. Середня частота сечовипускання протягом дня і ночі була $5,1 \pm 1,1$ і $2,0 \pm 0,5$ разів, відповідно.

Висновок. Проведення методики МП II передбачає створення резервуару з низьким тиском навіть при великих обсягах його наповнення, а стінки детубуляризованої та реконфігурованої кишки не мають скоординованих скорочень, що впиває на зменшення частоти кишково-сечовідного рефлюксу в нирки. Основним недоліком операції МП ІІ є наявність метаболічного ацидозу, що може було нівельовано амбулаторно.

Ключові слова: трансректальне відведення сечi, Mainz-pouch II.

\section{Адреса для листування}

О.Е. Стаховський

E-mail: stakhovsky9@gmail.com

А.В. Тимошенко

dr.tymoshenko@gmail.com

О.А. Войленко

E-mail: voilenko@rambler.ru

Ю.В. Вітрук

E-mail: uvitruk@ukr.net

Кононенко О.A.

E-mail: kononenko_ol@ukr.net

М.В. Пікуль

E-mail: urogenetics@gmail.com

Е.О. Стаховський

E-mail: estakhovsky@yahoo.com
Результаты. Интраоперационные осложнения при выполнении МП II возникли у 6 (5\%) больных. Осложнения в раннем послеоперационном периоде отмечено 29 (24,5\%) пациентов и связаны с нарушением функций органов и систем, инфекционно-гнойными воспалениями, несостоятельностью анастомоза. В отдалённом послеоперационном периоде осложнения выявлены у 71 (75,5\%) больного, что привели к развитию метаболического ацидоза $37(39,3 \%)$ и обострений инфекций верхних мочевых путей, в основе которых лежали: стеноз мочеточниковокишечного анастомоза $13(13,9 \%)$ и кишечномочеточниковый газовый рефлюкс $18(19,1 \%)$. Неконтролированное мочевыделение ночью отмечено у $3(3,1 \%)$ больных. Средняя частота мочеиспускания на протяжении дня и ночи была $5,1 \pm 1,1$ і 2,0土0,5 раз, соответственно.

Вывод. Проведение методики МП ІІ предусматривает создание резервуара с низким давлением даже при больших объемах его наполнения, а стенки детубуляризированного и реконфигурированого кишечного трансплантата не имеют скоординированных сокращений, что влияет на уменьшение частоты мочеточниково-кишечного рефлюкса в почки. Основным недостатком операции МП ІІ является наличие метаболического ацидоза, что может быть нивелировано амбулаторно.

Ключевые слова: трансректальная деривация мочи, Mainz-pouch II. 